\title{
Genetic parameters of body weight in japanese quails (Coturnix japonica Temminck \& Schlegel, 1849) in the Philippines
}

\author{
Angie R. Poliquit" ${ }^{1 *}$ and Agapita J. Salces ${ }^{2}$
}

\begin{abstract}
Submitted: 24 April 2019 | Accepted: 24 March 2020

The establishment of breeding and selection programs to improve the genetic potential of poultry necessitates estimation of genetic parameters for different production and reproduction traits. Restricted maximum likelihood (REML) software was used to estimate the heritability $\left(h^{2}\right)$ and genetic correlations $(r)$ of body weights in Japanese quails ( $C$. japonica) from hatch to fifth week of age. A total of 224 Japanese quails composed of 56 males and 168 females arranged in a Completely Randomized Design (CRD) served as the base population. Body weight records, measured weekly from hatch to fifth week, were utilized to estimate the genetic parameters. Heritability estimates were $0.093 \pm 0.004,0.244 \pm 0.010$, $0.031 \pm 0.001,0.082 \pm 0.004,0.325 \pm 0.016$ and $0.025 \pm 0.001$ for body weights at hatch $\left(\mathrm{BW}_{0}\right)$, first week $\left(\mathrm{BW}_{1}\right)$, second week $\left(\mathrm{BW}_{2}\right)$, third week $\left(\mathrm{BW}_{3}\right)$, fourth week $\left(\mathrm{BW}_{4}\right)$ and fifth week $\left(\mathrm{BW}_{5}\right)$, respectively. Low heritability estimates depict a decrease in additive genetic variance as the generations progressed. Negative genetic correlation was found between $\mathrm{BW}_{0}$ and $\mathrm{BW}_{4}(\mathrm{r}=-0.027)$. The significant positive genetic correlations of $\mathrm{BW}_{0}$ with $\mathrm{BW}_{1}(\mathrm{r}=0.271)$; $\mathrm{BW}_{1}$ with $\mathrm{BW}_{2}(\mathrm{r}=0.270), \mathrm{BW}_{3}$ $(r=0.294), B_{4}(r=0.255)$, and $B W_{5}(r=0.243) ; B_{2}$ with $B_{3}(r=0.561), B W_{4}(r=0.649)$, and $\mathrm{BW}_{5}(\mathrm{r}=0.503) ; \mathrm{BW}_{3}$ with $\mathrm{BW}_{4}(\mathrm{r}=0.726)$, and $\mathrm{BW}_{5}(\mathrm{r}=0.551)$; and $\mathrm{BW}_{4}$ with $\mathrm{BW}_{5}$ $(r=0.689)$ are expected to bring correlated responses in the other traits.
\end{abstract}

Keywords: Japanese quail, heritability, genetic correlation, body weight

\section{INTRODUCTION}

Awareness on Japanese quail raising particularly on meat production is beginning to gain the interest of farmers in the Philippines. But most producers find it difficult to establish an outstanding breeding program. The design of breeding

\footnotetext{
${ }^{1,2}$ Animal Breeding and Physiology Department, Institute of Animal Science, University of the Philippines Los Baños, College 4030, Laguna, Philippines
}

\footnotetext{
*Corresponding Author. Address: Institute of Animal Science, University of the Philipines Los Baños, College 4030, Laguna, Philippines; Email: angierefuerzo@gmail.com

DOI: 10.32945/atr4216.2020
} 
Genetic parameters of body weight in japanese quails

programs requires knowledge on genetic parameters for improving economically important traits determined under specific environmental conditions. Genetic parameters are necessary to predict the amount of improvement that can be achieved by direct and indirect selection (Harvey \& Bearden 1962).

Body weights are affected by genetic and non-genetic factors such as year and season of production, sex, nutrition, adaptability, climatic conditions and management (Hafez 1993). Estimation of heritability and correlations for weekly body weight in Japanese quails were extensively estimated by numerous researchers (Marks 1996, Kumari et al 2009, Narinc et al 2010, Zerehdaran et al 2012). Studies on the heritability of traits are essential for understanding how individual characteristics change from one generation to another in response to selection (Falconer \& Mackey 1996). Moreover, the genetic and environmental variations are described by the genetic parameters and vary among population and environments (Khaldari et al 2010).

The studies on genetic parameter estimation of quails in the Philippines if ever available are lacking and mostly focused on egg production. Hence, this study was geared towards estimating heritability and genetic correlations on weekly body weights in Japanese quails (C. japonica) from hatch to fifth week of age.

\section{MATERIALS AND METHODS}

The study was conducted at the University Animal Farm, Los Baños, Laguna, Philippines from April 2017 to December 2017. A total of 224 Japanese quails composed of 56 males and 168 females were arranged in a Completely Randomized Design (CRD) and served as the base population. The foundation stocks or base population placed inside double-tier battery-type cages served as treatment groups. A total of 56 families ( 1 sire: 3 dams) served as replicates.

The base population is part of the original random-bred population of Japanese quails that was purchased from Drquail Farm, Sariaya, Quezon. At the time of full egg production stage, eggs collected daily were identified based on sire families, and stored at room temperature. After seven days, all accumulated pedigreed eggs were properly sorted and set in setting trays based on sire families, artificially incubated at $37.5^{\circ} \mathrm{C}$ temperature and $65 \%$ relative humidity with automatic turning every three hours. At the end of the $14^{\text {th }}$ day of incubation, eggs were set in pedigree baskets in the egg hatcher. Immediately after hatching, the chicks were weighed and leg-banded according to their sire families, and artificially brooded for 21 days using 100-watt electric bulb as source of heat. The experimental quails (Generation 1 ) were fed with commercial chick starter mash with $\leq 24 \%$ crude protein (CP) and $2800 \mathrm{Kcal}$ per kg metabolizable energy (ME) as recommended by Dafwang (2006). The feed and water were supplied ad libitum during the entire duration of the study. Similarly, the brooding-rearing procedures were repeated on the quails of the next generation. Superior quails of generation 1 were selected as the parents of the second generation, and mated randomly at a mating ratio of 1 sire: 3 dams. The quails were weighed on a weekly interval from hatch to fifth week. On the fifth week of age, the birds were transferred to laying cages.

Data on body weight of Japanese quails from hatch to fifth week were analyzed using Statistical Analysis System (SAS) software ver. 9.2 to determine the results of fixed effects on growth values using the linear model presented in Table 1. 
Table 1. Linear model used in the analysis of variance of body weight of Japanese quails from hatch to fifth week of age

\begin{tabular}{lllll}
\hline Response Variable & Fixed Effects & Random Effects & Covariate & Error \\
\hline $\mathrm{BW}_{0-5}$ & Location $(1-8)$ & Generation $(\mathrm{n}=2)$ & Generation & $\mathrm{e}$ \\
& & Family $(\mathrm{n}=56)$ & Family & \\
& & & \\
\hline
\end{tabular}

BW means body weights from hatch to fifth week in grams; e=error

Simple statistics were obtained for body weight of the Japanese quail using the MEANS procedure of SAS $(2009)$. Only significant $(p<0.05)$ fixed effects and covariates were included in the final linear model, and the least square means procedure was used to examine the effect of generation on heritability trait.

The variance components for each body weight were obtained using the Restricted Maximum Likelihood Method (REML) by PROC VARCOMP of SAS 9.3 (SAS Institute Inc., Cary, $\mathrm{NC}$ ). The heritability $\left(\mathrm{h}^{2}\right)$ expresses the total proportion of the total variance that is attributable to differences of breeding values, and this is what determines the degree of resemblance between relatives (Falconer \& Mackay 1996). Heritability was calculated in each generation from sire variance component as (Becker 1985):

$$
h^{2}=\frac{2 \sigma^{2} s}{\sigma^{2} s+\sigma^{2} w}
$$

where:

$$
\begin{aligned}
& \sigma_{s}^{2}=\text { variance of sire } \\
& \sigma_{w}^{2}=\text { variance of remainder }
\end{aligned}
$$

Genetic correlation $(r)$ among reproduction traits were calculated using REML by PROC CORR of SAS 9.3 (SAS Institute Inc., Cary, NC).

\section{RESULTS AND DISCUSSION}

The data set for body weights contained the following records: 409 for at hatch $\left(\mathrm{BW}_{0}\right), 385$ for first week $\left(\mathrm{BW}_{1}\right), 347$ for second week $\left(\mathrm{BW}_{2}\right), 334$ for third week $\left(\mathrm{BW}_{3}\right)$, 334 for fourth week $\left(\mathrm{BW}_{4}\right)$ and 330 for fifth week $\left(\mathrm{BW}_{5}\right)$.

Japanese quails in Generation 1 were generally heavier than Generation 2. Specifically, body weights at third week $\left(\mathrm{BW}_{3}\right)$ were statistically higher $(\mathrm{p}<0.01)$ in Japanese quails at Generation $1(51.525 \mathrm{~g} \pm 7.915 \mathrm{~g})$ than at Generation 2 $(35.901 \mathrm{~g} \pm 6.493 \mathrm{~g})$ as shown in Table 2. Likewise, Japanese quails at week four $\left(\mathrm{BW}_{4}\right)$ were heavier $(p<0.05)$ at Generation $1(73.861 \mathrm{~g} \pm 10.100 \mathrm{~g})$ than Generation 2 $(57.243 \mathrm{~g} \pm 12.280 \mathrm{~g})$, see Table 2 . Result of this study was in contrast to the results obtained by Varkoohi et al (2011); Grasteau and Minvielle (2003) and Marks (1993) who reported that body weight increases with generation encouraging the application of selection for successive generations. 
Genetic parameters of body weight in japanese quails

Table 2. Weekly body weight $(\mathrm{g})$ of Japanese quails at Generation 1 and Generation 2 from hatch to fifth week of age

\begin{tabular}{lcccc}
\hline Trait & $\mathrm{n}$ & $\begin{array}{c}\text { Generation } 1 \\
(\text { Mean } \pm \text { SE) }\end{array}$ & $\mathrm{n}$ & $\begin{array}{c}\text { Generation 2 } \\
(\text { Mean } \pm \text { SE) }\end{array}$ \\
\hline $\mathrm{BW}_{0}$ & 262 & $6.126 \pm 1.041$ & 147 & $5.952 \pm 0.902$ \\
$\mathrm{BW}_{1}$ & 253 & $18.237 \pm 3.348$ & 132 & $14.068 \pm 2.162$ \\
$\mathrm{BW}_{2}$ & 233 & $32.957 \pm 5.275$ & 114 & $26.921 \pm 6.820$ \\
$\mathrm{BW}_{3}{ }^{* *}$ & 223 & $51.525 \pm 7.915^{\mathrm{a}}$ & 111 & $35.901 \pm 6.493^{\mathrm{b}}$ \\
$\mathrm{BW}_{4}{ }^{*}$ & 223 & $73.861 \pm 10.100^{\mathrm{a}}$ & 111 & $57.243 \pm 12.280^{\mathrm{b}}$ \\
$\mathrm{BW}_{5}$ & 220 & $90.941 \pm 10.302$ & 110 & $79.273 \pm 12.102$ \\
\hline
\end{tabular}

BW means body weight, in grams

**Significant at $p<0.01 ; *$ Significant at $p<0.05$

The variance component and heritability estimates for body weights of Japanese quails from hatch to fifth week of age are presented in Table 3. Heritability $\left(h^{2}\right)$ estimates were $0.093 \pm 0.004,0.244 \pm 0.010,0.031 \pm 0.001$, $0.082 \pm 0.004,0.325 \pm 0.016$ and $0.025 \pm 0.001$ for $\mathrm{BW}_{0}, \mathrm{BW}_{1}, \mathrm{BW}_{2}, \mathrm{BW}_{3}, \mathrm{BW}_{4}$ and $\mathrm{BW}_{5}$, respectively. The estimated low and moderate heritability values agreed with the results of several studies by different authors (Hussain et al 2014, Sezer 2007, Sezer et al 2006, Resende et al 2005, Akbas et al 2004). However, Kaplan et al (2016) and Aggrey and Cheng (1994) observed higher $h^{2}$ values with 0.63 and 0.38 , respectively. Estimates obtained for $\mathrm{BW}_{1}(0.244 \pm 0.010)$ and $\mathrm{BW}_{2}(0.031 \pm 0.001)$ were lower compared to the reported values of Kaplan et al (2016) with 0.42 and 0.40 , respectively. The $\mathrm{h}^{2}$ for $\mathrm{BW}_{3}(0.082 \pm 0.004)$ closely agreed to the estimates (0.01-0.18) of Hussain et al (2014) and Akbas et al (2004). Mostly, results of some studies conducted by a number of researchers have relatively higher estimates ( $0.43 \& 0.58)$ (Resende et al 2005, Saatci et al 2006). At week four age of quails, variable $h^{2}$ estimates were recorded by a number of researchers as $0.03,0.19$, and 0.61 by Hussain et al (2014); Saatci et al (2006); and Akbas et al (2004). The heritability estimate at $\mathrm{BW}_{4}(0.325 \pm 0.016)$ conformed to the heritability values of 0.22-0.47 by Varkoohi et al (2011) and Abdullah et al (2011). Meanwhile, heritability of quails at $\mathrm{BW}_{5}(0.025 \pm 0.001)$ was lower than other studies with estimates ranging from 0.35 to 0.55 (Kaplan et al 2016, Narinc et al 2014, Sari et al 2011, Narinc et al 2010, Aksit et al 2003). In this study, the lower $h^{2}$ estimates might be due to the small data set involving less number of birds in two generations. Mehrgardi (2012) also estimated lower heritability values in advanced generations of Japanese quail depicting a decrease in additive genetic variance as the generations progressed in long-term selection. 
Poliquit \& Salces

Table 3. Variance component and heritability estimates for body weight of Japanese quailsat from hatch to fifth week of age

\begin{tabular}{lccc}
\hline \multirow{2}{*}{ Trait } & \multicolumn{2}{c}{ Variance Component } & $\begin{array}{c}\text { Heritability } \\
\left(\mathrm{h}^{2} \pm \mathrm{SE}\right)\end{array}$ \\
\cline { 2 - 3 } $\mathrm{BW}_{0}$ & Among Sire & Within Sire & $0.093 \pm 0.004$ \\
$\mathrm{BW}_{1}$ & 0.045 & 0.922 & $0.244 \pm 0.010$ \\
$\mathrm{BW}_{2}$ & 1.113 & 8.000 & $0.031 \pm 0.001$ \\
$\mathrm{BW}_{3}$ & 0.520 & 33.412 & $0.082 \pm 0.004$ \\
$\mathrm{BW}_{4}$ & 2.312 & 53.748 & $0.325 \pm 0.016$ \\
$\mathrm{BW}_{5}$ & 29.950 & 154.256 & \\
\hline
\end{tabular}

In the present study, except for $\mathrm{BW}_{0}$ withBW $\mathrm{W}_{4}$ the, genetic correlations were positive, ranging from 0.271 to 0.689 (Table 4 ). Table 4 revealed strong genetic correlations estimated between weekly body weights, except for the correlation between $\mathrm{BW}_{0}$ with $\mathrm{BW}_{2}(r=0.002), \mathrm{BW}_{3}(r=0.033)$ and $\mathrm{BW}_{5}(r=0.016)$. Negative genetic correlation was found between $\mathrm{BW}_{0}$ and $\mathrm{BW}_{4}(\mathrm{r}=-0.027)$. The significant $(p<0.001)$ positive genetic correlations of $\mathrm{BW}_{0}$ with $\mathrm{BW}_{1}(\mathrm{r}=0.271)$; $\mathrm{BW}_{1}$ with $\mathrm{BW}_{2}(\mathrm{r}=0.270)$, $\mathrm{BW}_{3}(\mathrm{r}=0.294), \mathrm{BW}_{4}(\mathrm{r}=0.255)$, and $\mathrm{BW}_{5}(\mathrm{r}=0.243) ; \mathrm{BW}_{2}$ with $\mathrm{BW}_{3}(\mathrm{r}=0.561), \mathrm{BW}_{4}$ $(\mathrm{r}=0.649)$, and $\mathrm{BW}_{5}(\mathrm{r}=0.503) ; \mathrm{BW}_{3}$ with $\mathrm{BW}_{4}(\mathrm{r}=0.726)$ and $\mathrm{BW}_{5}(\mathrm{r}=0.551)$; and $\mathrm{BW}_{4}$ with $\mathrm{BW}_{5}(\mathrm{r}=0.689)$ are expected to bring correlated responses in the other traits. The accurate selection for body weight at $\mathrm{BW}_{5}$ can be achieved based on body weight at $\mathrm{BW}_{4}$ because the 2 traits show a genetic correlation of 0.689 implying favorable individuals for body weight at $\mathrm{BW}_{4}$ should also be the most desirable for body weight at $\mathrm{BW}_{5}$.

Table 4. Genetic correlations among body weights of Japanese quails from hatch to fifth week of age

\begin{tabular}{lrcllll}
\hline Trait & $\mathrm{BW}_{0}$ & $\mathrm{BW}_{1}$ & $\mathrm{BW}_{2}$ & $\mathrm{BW}_{3}$ & $\mathrm{BW}_{4}$ & $\mathrm{BW}_{5}$ \\
\hline $\mathrm{BW}_{0}$ & 1.000 & $0.271^{\star \star \star}$ & 0.002 & 0.033 & -0.027 & 0.016 \\
$\mathrm{BW}_{1}$ & & 1.000 & $0.270^{\star \star \star}$ & $0.294^{\star \star \star}$ & $0.255^{\star \star \star}$ & $0.243^{\star \star \star}$ \\
$\mathrm{BW}_{2}$ & & & 1.000 & $0.561^{\star \star \star}$ & $0.649^{\star \star \star}$ & $0.503^{\star \star \star}$ \\
$\mathrm{BW}_{3}$ & & & 1.000 & $0.726^{\star \star \star}$ & $0.551^{\star \star \star}$ \\
$\mathrm{BW}_{4}$ & & & & 1.000 & $0.689^{\star \star \star}$ \\
$\mathrm{BW}_{5}$ & & & & & 1.000 \\
\hline
\end{tabular}

***-significant at $p<0.001$ 
Genetic parameters of body weight in japanese quails

The highest genetic correlation estimate between $\mathrm{BW}_{3}$ with $\mathrm{BW}_{4}(\mathrm{r}=0.726)$ was slightly lower compared to the findings of Sezer (2007) who disclosed higher genetic correlation values for weekly body weights as $r_{91-2}=0.89, r_{g 2-3}=0.94, r_{g 3-4}=0.93$, $r_{g 4-5}=0.92$, and $r_{g 5-6}=0.96$. Similarly, Sezer et al (2006) reported the genetic correlations range from 0.46 to 0.98 between weekly body weights. Akbas et al (2004) reported genetic correlations estimates for weekly body weights between $2-4,2-6$ and $4-6$ weeks as $0.84,0.80$ and 0.80 , respectively. Although the estimates did not correspond with the published reports (eg, Sezer 2007, Sezer et al 2006, Akbas et al 2004), differences in the on-farm research setting and procedures should not be overlooked.

\section{ACKNOWLEDGMENT}

The author would like to thank the Accelerated Science and Technology for Human Development Program (ASTHRDP) under the Department of Science and Technology (DOST).

\section{REFERENCES}

Abdullah RB, Wan Embong WK \& Soh HH. 2011. Biotechnology in animal production in developing countries. Proceedings of the 2nd International Conference on Agricultural and Animal Science (pp88-91), November 25-27, 2011, Singapore

Aggrey SE and Cheng KM. 1994. Animal model analysis of genetic (co)variance of growth traits in Japanese quail. Poultry Science 73(12):1822-1828

Akbaş Y, Takma C \& Yaylak E. 2004. Genetic parameters for quail body weights using a random regression model. South African Journal of Animal Science 34(2):104-109

Aksit M, Oguz I, Akbas Y, Altan O \& Ozdogan M. 2003. Genetic variation of feed traits and relationships to some meat production traits in Japanese quail (Coturnix coturnix Japonica). Archiv fur Geflugelkunde 67(2):76-82

Becker WA. 1985. Manual of Quantitative Genetics (4th edn). Academic Enterprises, Pullman, Washington, USA

Dafwang II. 2006. Nutrient requirements and feeding regiment in Quail production. A paper presented at the National Workshop on Quail Production for sustainable household protein intake (pp12-19). National Agricultural Extension and Research Liason Services, Ahmadu Bello University, Zaria, Nigeria. September 11th-13th

Falconer DS and Mackay TFC. 1996. Introduction to Quantitative Genetics (4th edn). Longman Group Ltd., UK

Grasteau SM and Minvielle F. 2003. Relation between tonic immobility and production estimated by factorial correspondence analysis in Japanese quail. Poultry Science 82:1839-1844

Hafez ES. 1993. Reproduction in Farm Animals (6th edn). Lea and Febiger, Philadelphia, USA

Harvey WR and Bearden GD. 1962. Tables of expected genetic progress in each two traits. Agricultural Research Services 20-12, USDA

Hussain J, Akram M, Sahota AW, Javed K, Ahmad HA \& Mehmood S. 2014. Selection for higher three-week body weight in Japanese quail:2. Estimation of genetic parameters. Journal of Animal and Plant Sciences 24(3):869-873 
Kaplan S, Narinc D \& Gurcan EK. 2016. Genetic parameter estimates of weekly body weight and Richard's growth curve in Japanese quail. European Poultry Science 80:1-10

Khaldari M, Pakdel A, Mehrabani Yegane H, Nejati Javaremi A \& Berg P. 2010. Response to selection and genetic parameters of body and carcass weights in Japanese quail selected for 4-week body weight. Poultry Science 89(9):18341841

Kumari PB, Gupta BR, Prakash MG \& Reddy AR. 2009. Genetic study on body weights of Japanese quails. International Journal of Poultry Science 44:301307

Marks HL.1993. Carcass composition, feed intake, and feed efficiency following long term selection four week body weight in Japanese quail. Poultry Science 72(6):1005-1011

Marks HL.1996. Long-term selection for body weight in Japanese quail under different environments. Poultry Science 75(10):1198-1203

Mehrgardi AA. 2012. Divergent selection of four-week body weight in Japanese quail (Coturnix coturnix japonica): response to selection and realized heritability. Journal of Livestock Science and Technologies 1(1):61-63

Narinç D, Aksoy T, Karaman E \& Firat MZ. 2014. Genetic parameter estimates of growth curve and reproduction traits in Japanese quail. Poultry Science 93(1):24-30

Narinc D, Aksoy T \& Karaman E. 2010. Genetic parameters of growth curve parameters and weekly body weights in Japanese quail. Journal of Animal and Veterinary Advances 9(3):501-507

Resende RO, Martins EN, Georg PC, Paiva E, Conti ACM, Santos Al, Sakaguti ES \& Murakami AE. 2005. Variance components for body weight in Japanese quails (Coturnix japonica). Brazilian Journal of Poultry Science 7(1):23-25

Saatci M, Omed H \& Dewi IAP. 2006. Genetic parameters from univariate and bivariate analyses of egg and weight traits in Japanese quail. Poultry Science 85:185-190

Sarı M, Tilki M \& Saatci M. 2011. Genetic parameters of slaughter and carcase traits in Japanese quail (Coturnix coturnix japonica). British Poultry Science 52(2):169-172

Sezer M. 2007. Genetic parameters estimated for sexual maturity and weekly live weights of Japanese quail (Coturnix coturnix japonica). Asian-Australasian Journal of Animal Science 20(1):19-24

Sezer M, Berberoğlu E \& Ulutaş Z. 2006. Genetic association between sexual maturity and weekly live-weights in laying-type Japanese quail. South African Journal of Animal Science 36(2):142-148

Statistical Analysis Systems (SAS). 2009. SAS/STAT guide for personal computers, version 9.2. SAS Institute Inc., Cary, North Carolina, USA

Varkoohi S, Pakdel A, Moradi M, Nejati A, Kause A \& Zaghari M. 2011. Genetic parameters for feed utilization traits in Japanese quail. Poultry Science 90:4247

Zerehdaran S, Lotfi E \& Rasouli Z. 2012. Genetic evaluation of meat quality traits and their correlation with growth and carcass composition in Japanese quail. British Poultry Science 53:756-762 